\title{
Developing Value Proposition for Business Models of National Iranian Oil Companies
}

\author{
Mohammadreza KHORSHIDI \\ The Bucharest University of Economic Studies, Bucharest, Romania \\ m.khorshidi@live.com
}

\begin{abstract}
The Value proposition is one of the key aspects of a business model and plays a significant role in any business model. Nowadays, firms could be successful and even could be initiated, only when a value proposition of their business model is clarified precisely. There is a necessity for new studies in order to see whether National Oil Companies(NOCs) are promoting the proper business models that make them competitive. This research analyzes the value proposition and its influence on the NOC's competitiveness and it supports to deliver the required products and services to their specific market segment and customers. The main objective of this research is to develop a value proposition for the business model of National Oil Companies(NOCs). This could enable firms to be more competitive in the oil industry, especially in the oil supply glut circumstance. In order to achieve this objective, the research methodology is based on the semi-structured interview with the main stakeholders in the oil industry which is NOCs. First, value propositions in the history of oil and gas industry are addressed in almost every decade, then five current or previous managers of National Iranian Oil Company are selected for the semi-structured interview to clarify the current market situation and eventually propose the desired value propositions for the business model of NOCs.
\end{abstract}

Keywords: value proposition, business model, national oil companies, supply glut, supply surplus.

\section{Introduction}

A value proposition is a positioning statement that explains what benefit you provide for who and how you do it uniquely well (Skok, 2013). Some factors are critical reaching us to the value proposition. We should know the target buyer, the problem, and our competitive advantage in comparison with other alternatives. In this case, four steps are required to achieve a compelling value proposition. Defining the problem, evaluate whether your breakthrough is unique and compelling, Measure potential customer adoption using the gain/pain ratio, and finally, Build the value proposition (Skok, 2013).

A product's value proposition is a statement of the functional, emotional and selfexpressive benefits delivered by the brand that provide value to the target customer." (Aaker, 1996). Another viewpoint exists while we talk about the value proposition and it is customer value proposition. It is talking about the market and firm experience that a customer who is targeted by the firm, could unveil when using the firm's products and services or buy them (Hudadoff, 2009).

Eventually, by considering the nine-building block's Osterwalder business model canvas, it determines that value proposition has a direct connection with customer segment. It means, customer requirements in any sector is the key factor to obtain value proposition of a firm and as a result, provide required solutions by achieving products and services to provide all or a specific share of customer requirements. To simplify the value proposition concept, it is a reason that a customer should convince using the firm's products and services instead of using other firms. in this case, a unique value should be 
assumed for contenders (Osterwalder et all, 2014). Nevertheless, the value proposition which derived from the business model canvas is the solution of which problems that could provide related products and services. In order to provide the best, unique solution by introducing related products and services, we should consider customer sectors expectations to obviate their necessity as a desire product and services which could even support multiple value proposition for their customers. (Osterwalder et all, 2014).

Table 1. Triple bottom line business model canvas

\begin{tabular}{|c|c|c|c|c|}
\hline \multicolumn{2}{|c|}{ Infrastructure Management } & \multirow{2}{*}{$\frac{\text { Product }}{\text { Value Propositions }}$} & \multicolumn{2}{|c|}{ Customer Interface } \\
\hline Key Partners & Key Resources & & $\begin{array}{l}\text { Customer } \\
\text { Segments }\end{array}$ & $\begin{array}{c}\text { Customer } \\
\text { Relationships }\end{array}$ \\
\hline \multicolumn{2}{|c|}{ Key activities } & & \multicolumn{2}{|c|}{ Channels } \\
\hline \multicolumn{5}{|c|}{ Financial Aspects } \\
\hline \multicolumn{3}{|c|}{ Cost Structure } & \\
\hline \multicolumn{3}{|c|}{ Social \& Environmental costs } & \multicolumn{2}{|c|}{$\frac{\text { Revenue Stream }}{\text { Social \& Environmental benefits }}$} \\
\hline
\end{tabular}

Although all firms try to provide the new unique solutions for their customers, there are some undeserved requirements which never support by any firm and it could be a key success of a new firm or a new value proposition of an existing firm. On the other end, unavoidable, unworkable, urgent problems are not vague for firms which are looking for customers' requirements. Therefore, those problems could clarify earlier than undeserved ones, and the key success for those problems is that any firm which could be the pioneer in supporting a unique solution, could be successful and be the choice of customers.

Each value proposition should meet some unique and specific criteria to cover customer requirements in the desired market segment. One of the new workable methods of forming a value proposition is thinking about customer's expectation. In this case, I want to refer to a famous cite which doesn't find customers for your products, find products for your customers (Godin, 2009).

In order to support customers' expectation and provide a unique product or services, some properties could be considered for them to form the firm's roadmap to obtain its products and services.

Regarding some features like the brand, usability, and design which are almost traditional features of each product and service, Firms should pay attention to some features like customization, accessibility, performance, and newness. These features have more concentration on customers' requirements to provide a better and convenient product and service. Although newness is the best key factor for a firm to absorb customers, lack of performance and accessibility could tend the firm to be unsuccessful and lose the market. Cost reduction and risk reduction are also other features of a good value proposition. Customers should have enough motivation to choose a product or service which less cost to obtain or less risk to use them could be good enough motivation factors in the case of choosing a product or service. Following is the table of aforementioned features to illustrate them better. 
Table 2. Value Proposition features

\begin{tabular}{|l|l|}
\hline Value Proposition & For What? \\
\hline Newness & Provide a new request in the market and be pioneer \\
\hline Accessibility & Easy to find and obtain by using various delivery channel \\
\hline Performance & $\begin{array}{l}\text { To be always up to date and provide new feature by improving } \\
\text { product's characteristics }\end{array}$ \\
\hline Brand & $\begin{array}{l}\text { Looking for loyal customers and improve brand equity in the } \\
\text { market }\end{array}$ \\
\hline Price & $\begin{array}{l}\text { Enter the market successfully as a follower and compete with } \\
\text { existing firm by price }\end{array}$ \\
\hline Design & $\begin{array}{l}\text { To provide better customer's feeling and cover more } \\
\text { expectations by better, unique and useful design }\end{array}$ \\
\hline Cost reduction & To meet customers' requirement in affordability \\
\hline Risk reduction & $\begin{array}{l}\text { Decrease customer's risk by providing warranty or any other } \\
\text { productivity and safety support program }\end{array}$ \\
\hline Convenience & $\begin{array}{l}\text { Respect customers to use products and services for peace in } \\
\text { their mind }\end{array}$ \\
\hline
\end{tabular}

PICBE | 510

Source: Cleverism, 2017.

Figure 1, could shape entrepreneur's mind to provide a precise arrangement of customer requirements. The first step as illustrated in figure 1, is concentrating on customer segment and analyze three key factors which are customers' job, customers' pain and customers' gain.
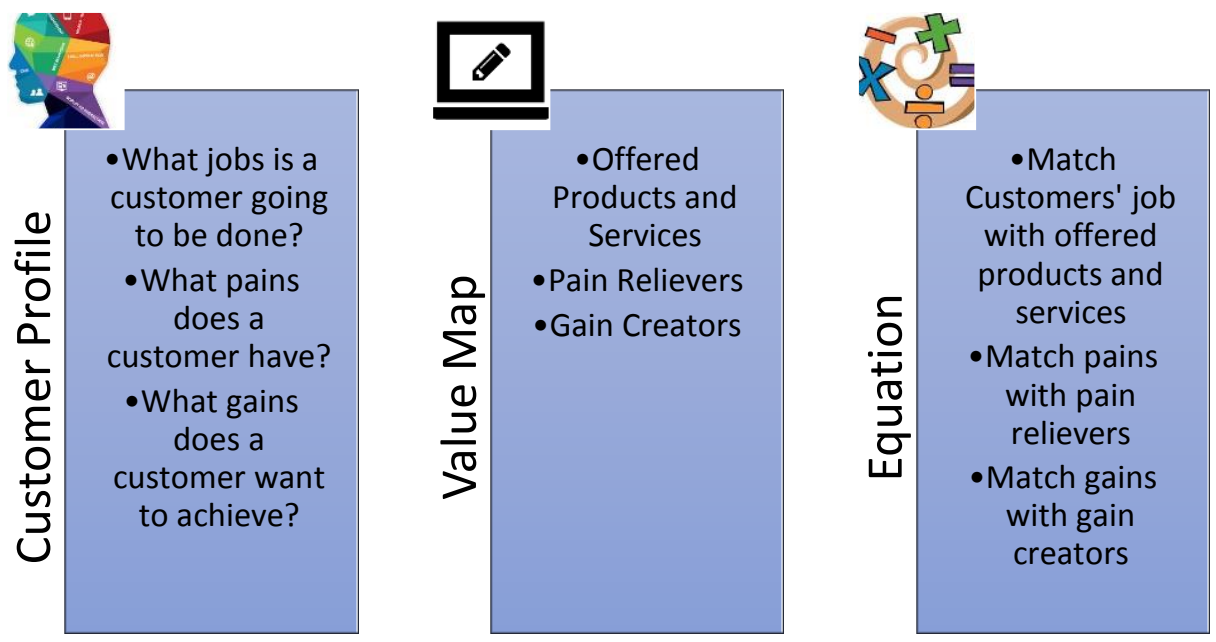

Figure 1. Value Proposition Ingredients

Source: Osterwalder \& Pigneur, 2015.

In practice, there are also situations when for a specific segment of the value chain there is no value proposition (e.g. at present the distributed energy field). Therefore, in the future, there is a potential to develop new services in this field (e.g. ESCO services) that could represent a new value proposition for the customers. (Tantau A. et al., 2017) 


\section{Literature review}

Oil and gas industry as one of the traditional industries which has more than a century experience globally still plays a major role in the global energy market by considering PICBE $\mid 511$ mandatory changes in its players' business model. Although fossil energy still supplies the majority of the energy consumption shares in all over the world, Companies which are in this field experienced many change based on the market situation and required environmental essentials.

Oil and gas companies faced with various factors which caused alteration and renovation in their value proposition to retain their company in the market. From 1859, which oil was discovered by Colonel Drake till now, there have been many pains and gains and jobs which customers want to be done in the oil and gas industry. Absolutely, crude oil solely was itself a value proposition as a newly discovered material and it had proposed gains to the people lifestyle for many years. On the other end, some International Oil Companies were established to handle exploration, extraction, and production of oil and gas products. After unveiling oil and gas advantages, companies faced with the first key trouble which was nationalization in the 1940s. before this time, the oil industry was dominated by seven giant IOCs which five of them were originally from the North America like Chevron, Exxon, Texaco, Mobil and Gulf, and one of them was the Royal-Dutch Shell(Anglo-Dutch), and the last one was British Petroleum(Angle-Persia). (Bird \& Brown, 2005). To evaluating the value proposition estate, we can consider two separate time-periods for oil industry which could be before nationalization and after nationalization.

In the second era, some factors could be considered which affect on the value proposition of the oil and gas companies. regardless of the types of companies, like IOCs or NOCs, oil industry faced with a new challenge which was $\mathrm{CO} 2$ emission problem. It is also known as pollution and had had many years' history which was known by smog and soot. In the 1950s, people notified by another pollution resources which also is the most polluting industry in the world, like fossil energy and its pollution result, which is C02. Scientists found out the oil industry is the major pollution resource. For instance, smog from oil refineries, NO2 and hydrocarbons which do not combust and formed in cars (Banerjee et all, 2016).

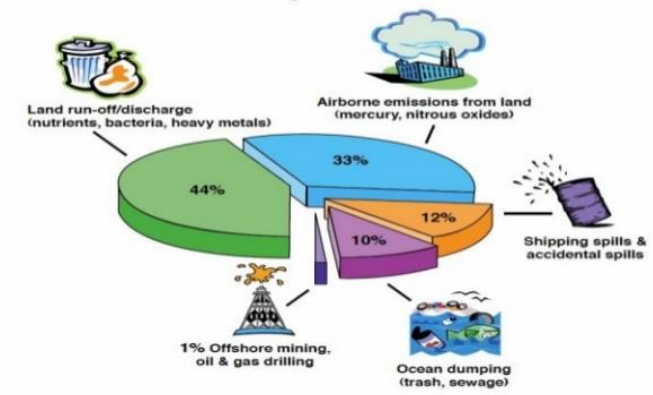

Figure 2. Pollution causes, effects, and solutions

Source: FB kh \& F B khj, 2014, Technology, Health \& Medicine.

Oil industry faced with major crisis derived from Arab oil producers embargo and later, Iran revolution in the 1970s. The oil price started to rise to its highest historical range, about $40 \$$. Other oil producer countries decided to overcome the situation in the future and eventually, they started to build Strategical Petroleum Reserve(SPR) which have lead by the United States since 1975. Using SPR let countries to store desired oil or petroleum products 
in their strategical reserves and release them in the time of any crisis to control the market price and avoid any difficulties for consumers and industries which are using petroleum products as their feedstock (Upadhyay, 2017).

According to the EIA, Crude oil production hit a record in the early 1980s while the price was in the historical highest range around $40 \$$ which is about $100 \$$ by converting the USD value by Consumer Price Index(CPI) to today USD value. Customers started to avoid extra usage of the fossil energy by driving less and buy lesser fossil energy products. Eventually, crude oil price declined to almost $10 \$$ in mid of the 1980s (Murray, 2017). OPEC countries decided to manipulate their production and IOCs tried to avoid investing in new exploration and stop producing in high-cost fields. They also tried to think about how to store their production in crude stockpiles and control supplying rate in the supply glut situation (Denning, 2017).

The low market continued for almost five years till the beginning of the 1990s which crude oil price hiked again by starting the Persian Gulf crisis and the war in Iraq. This time as the market were in the stable situation for both suppliers and consumers, OPEC and other major producers again manipulate the market to compensate lack of production in the war area. Therefore, high prices couldn't continue more than a few months and declined to its stable range though it had some fluctuation due to other political triggers. Again, crude oil price declined sharply to around $10 \$$ due to Asian financial crisis. As a result, the most important alliance formed in the history of the oil industry by merging giant IOCs. BPAmoco, BP-Arco, Exxon-Mobil, Chevron-Texaco, and Conoco-Phillips formed eventually (Murray, 2017).

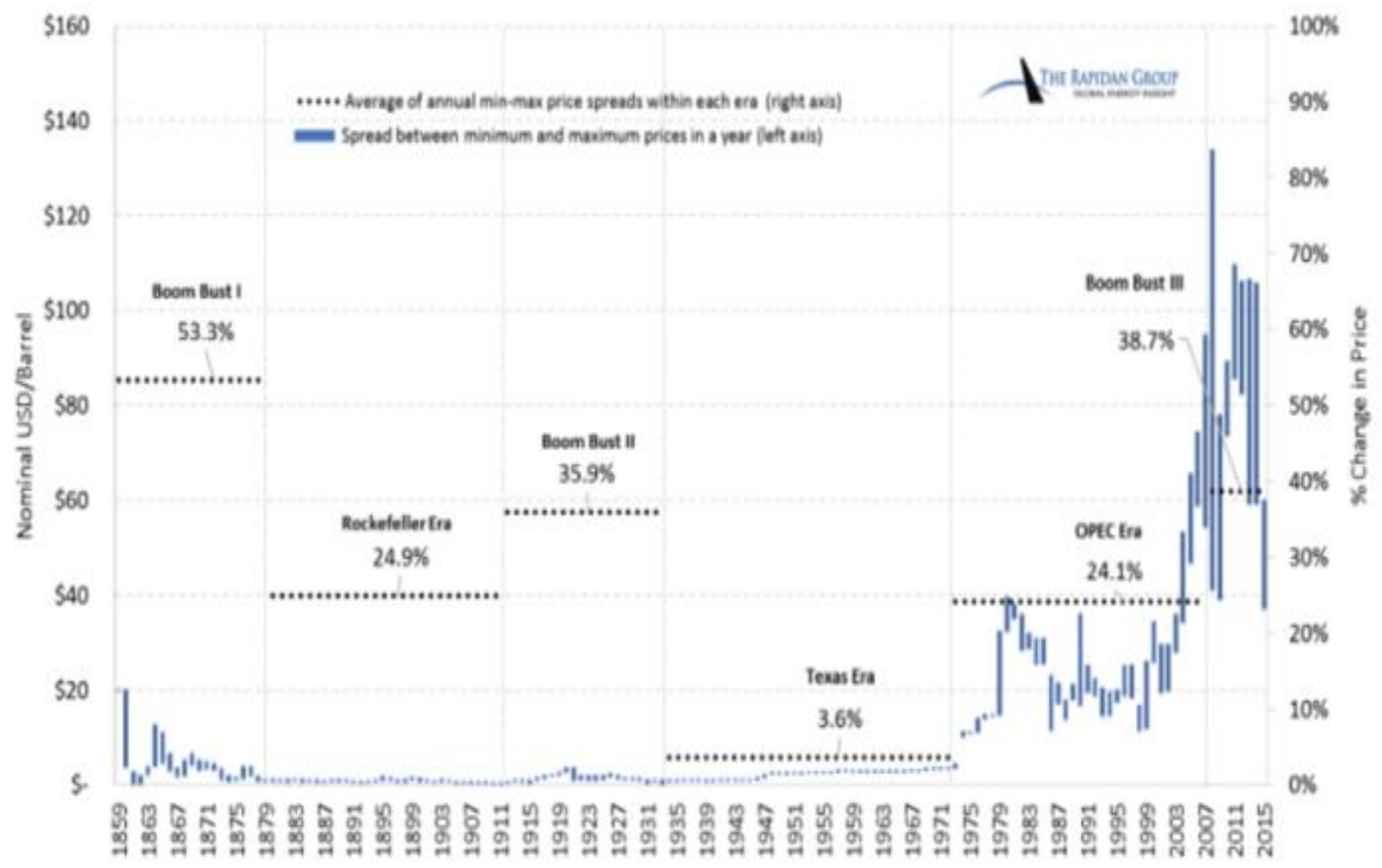

Figure 3. Crude oil Price Ranges, 1859-2016

Source: The Rapidan Group based on The Derrick, API, EIA, Louis Fed and Bloomberg. 
Oil industry faced with multiple conflicts in 2000s such as Middle East crisis and global recession which started in the United States and widespread globally. In this decade, IOCs lost the market to the NOCs, as NOCs manipulate their oil reserves and own the majority of oil reserves in the world. Although in the late 1990s huge merge occurred in IOCs to revive their role in the market, lack of cheap reserves and loss of full control on their contracts with NOCs, and lack of financial supports derived from IOCs weak dividend to their shareholders caused IOCs lost their control on the market. IOCs had to lose their technological and management on their contracts and shrink their assets to avoid any further problems (Haslam \& Heidrich, 2016).

Later than oil price spike which derived from oil reserves manipulation by NOCs and political crisis in the middle east which is the highest oil reserves owners globally, the United States shale oil discovery and eventually, increases in SPR levels caused another supply glut and market slow down. According to EIA, crude oil price which dropped dramatically from around $140 \$$ in the mid-2014 to below $30 \$$, slightly started to rise again and be stable in the range of $50 \$$. Moreover, environmental concerns getting more crucial which NOCs and IOCs both have to consider the sustainable Exploration and Production.

\section{Research objectives}

The main objective of this research is to develop the value proposition for the business model in the oil industry. This could enable firms to be more competitive in the oil industry, especially in the oil supply glut situation which could cause a market slowdown. In this research by considering historical information of oil industry and comparing derived information in which different market states, the value proposition of oil and gas companies in supply glut situation is considered and developed.

Study on the historical information which was done by the oil and gas companies in the same market situation could lead us to our objective, though it's not good enough. we should consider major changes which occurred based on the other market or industry attributes. Improvements in the oil industry in technological aspects or in any other aspects may lead us to a different value proposition than the same, previous market situation. According to the research objective, following hypotheses are probable.

Hypothesis 1: Consolidation is the most overwhelming value proposition for NOCs to revive the market

Hypothesis2: NOCs have the better efficiency if they make contract with an integrated Exploration and Production(E\&P) companies instead of splitting the contract among different service companies

Hypothesis3: knowledge localization and using domestic resources is more efficient for NOCs instead of using IOCs.

\section{Research methodology}

The research methodology is based on the semi-structured interview with the main stakeholders in the oil industry. In this case, as the semi-structured interview should be done in the same industry sector and achieve results based on the same questions, first we designated required questionnaire and adjusted it on which specific industry and market situation. The population which is national oil companies should be divided into different groups. For instance, categorize them based on which activity in the oil industry, then 
interview their selected representative and finally, gather all information from interviews and achieve results of the population (Saunders et al., 2009).

Difference between unstructured and structured interview is on the methods of the PICBE | $\mathbf{5 1 4}$ interview. In the structured interview, the questionnaire should be designated before any interview and interviewer, should ask the same questions based on the designated questionnaire, from stakeholders, while the unstructured interview is almost a normal colloquium (David \& Sutton, 2011).

Interviews are done by five senior managers of the National Oil Companies, which have required and critical information from their companies. Those senior managers selected based on their roles and responsibilities in their companies, and also in different activity. Then all answers, matched by the map of the value proposition and finally, all data is concluded based on the interviews and adjusted map.

\section{Research analysis and results}

In this part of the research, first, all information regarding the oil industry history has gathered. Information which is in table2, have gathered since the 1850s to 2017 according to the historical information and related oil price data. All details regarding this table are in literature review section of this research by considering their references. Afterward, by a designated interview's related questionnaire and asking from five companies' representatives, Value Proposition(VP) of NOCs is evaluated and clarified what their attitude is to obtain their VP.

Table 3. Value Proposition in the oil industry history since the 1850s to 2017

\begin{tabular}{|c|c|c|c|c|c|}
\hline $\begin{array}{l}\text { Time } \\
\text { series }\end{array}$ & $\begin{array}{l}\text { Historical } \\
\text { info. }\end{array}$ & Pains & Gains & Jobs to be done & $\begin{array}{l}\text { Value } \\
\text { Proposition } \\
\end{array}$ \\
\hline $1850 \mathrm{~s}$ & $\begin{array}{l}\text { The first oil } \\
\text { well } \\
\text { discovered }\end{array}$ & $\begin{array}{l}\text { Lack of long } \\
\text { last energy } \\
\text { sources }\end{array}$ & $\begin{array}{l}\text { New source of } \\
\text { energy to support } \\
\text { most of the } \\
\text { consumers' needs }\end{array}$ & $\begin{array}{l}\text { Using oil as the new } \\
\text { source of energy in } \\
\text { industries }\end{array}$ & $\begin{array}{l}\text { Lighting, new } \\
\text { Source of energy }\end{array}$ \\
\hline $\begin{array}{l}1860 \mathrm{~s} \\
\text { to } \\
1900 \mathrm{~s}\end{array}$ & $\begin{array}{l}\text { The Second } \\
\text { Industrial } \\
\text { Revolution }\end{array}$ & $\begin{array}{l}\text { Crude oil } \\
\text { delivery } \\
\text { problem }\end{array}$ & $\begin{array}{l}\text { Technology used } \\
\text { to refine kerosene } \\
\text { from crude oil in } \\
\text { refineries, } \\
\text { pipelines came to } \\
\text { help crude oil and } \\
\text { kerosene delivery }\end{array}$ & $\begin{array}{l}\text { Refineries was } \\
\text { established, } \\
\text { pipelines for crude } \\
\text { oil delivery was } \\
\text { made }\end{array}$ & $\begin{array}{l}\text { Faster transport, } \\
\text { higher power } \\
\text { generators }\end{array}$ \\
\hline $\begin{array}{l}1900 s \\
\& \\
1910 s\end{array}$ & $\begin{array}{l}\text { Oil industry } \\
\text { expansion }\end{array}$ & $\begin{array}{l}\text { Lack of desired } \\
\text { fuel for } \\
\text { automobile } \\
\text { and airplane }\end{array}$ & $\begin{array}{l}\text { Gasoline } \\
\text { production }\end{array}$ & $\begin{array}{l}\text { Achieving desired } \\
\text { product for } \\
\text { automobile and } \\
\text { airplane to use as } \\
\text { their fuel }\end{array}$ & $\begin{array}{l}\text { Individual } \\
\text { Transport by car } \\
\text { or plane }\end{array}$ \\
\hline $\begin{array}{l}1920 s \\
\& \\
1930 s\end{array}$ & $\begin{array}{l}\text { Explore oil in } \\
\text { all parts of the } \\
\text { world, WWI \& } \\
\text { WWII }\end{array}$ & $\begin{array}{l}\text { Oil supply for } \\
\text { war, better } \\
\text { quality, and } \\
\text { purer products } \\
\text { was needed, oil } \\
\text { depletion } \\
\text { anxiety }\end{array}$ & $\begin{array}{l}\text { Technological } \\
\text { progress, organize } \\
\text { oil industry by } \\
\text { establishing } \\
\text { international } \\
\text { institutes }\end{array}$ & $\begin{array}{l}\text { new global oil fields } \\
\text { discovery, more } \\
\text { quality products } \\
\text { achievement }\end{array}$ & $\begin{array}{l}\text { Better quality } \\
\text { fuel for } \\
\text { airplanes, } \\
\text { technological } \\
\text { products, and } \\
\text { equipment }\end{array}$ \\
\hline $1940 \mathrm{~s}$ & $\begin{array}{l}\text { Oil } \\
\text { nationalization }\end{array}$ & $\begin{array}{l}\text { Oil reserves } \\
\text { ownership }\end{array}$ & $\begin{array}{l}\text { Oil reserves } \\
\text { ownership }\end{array}$ & $\begin{array}{l}\text { Alteration in types } \\
\text { of contracts, oil }\end{array}$ & adaptability \\
\hline
\end{tabular}




\begin{tabular}{|c|c|c|c|c|c|}
\hline & & $\begin{array}{l}\text { anxiety in oil } \\
\text { countries }\end{array}$ & & $\begin{array}{l}\text { producer countries } \\
\text { became rich }\end{array}$ & \\
\hline 1950s & CO2 emission & CO2 emission & $\begin{array}{l}\text { Evaluation oil and } \\
\text { gas companies' } \\
\text { pollution ratio }\end{array}$ & $\begin{array}{l}\text { Research started to } \\
\text { obtain technological } \\
\text { solution to cut } \\
\text { carbon dioxide }\end{array}$ & sustainability \\
\hline $1960 s$ & $\begin{array}{l}\text { OPEC } \\
\text { Formation }\end{array}$ & $\begin{array}{l}\text { Lack of } \\
\text { sovereignty on } \\
\text { oil producer's } \\
\text { countries over } \\
\text { their resources }\end{array}$ & $\begin{array}{l}\text { Sovereignty on } \\
\text { resources for oil } \\
\text { producer's } \\
\text { countries }\end{array}$ & $\begin{array}{l}\text { New business model } \\
\text { created as National } \\
\text { oil companies(NOC) } \\
\text { were formed }\end{array}$ & $\begin{array}{l}\text { flexibility \& } \\
\text { cooperation }\end{array}$ \\
\hline $1970 s$ & $\begin{array}{l}1973 \text { Arab oil } \\
\text { embargo, } 1979 \\
\text { Iran revolution }\end{array}$ & $\begin{array}{l}\text { Oil supply } \\
\text { problem } \\
\text { because of } \\
\text { political } \\
\text { problem }\end{array}$ & $\begin{array}{l}\text { Oil price surge } \\
\text { could be } \\
\text { considered as a } \\
\text { gain for producer } \\
\text { countries but not } \\
\text { for customers }\end{array}$ & $\begin{array}{l}\text { The first Oil } \\
\text { production boom, } \\
\text { better life style for } \\
\text { producer countries, } \\
\text { Decision to build } \\
\text { Strategical } \\
\text { Petroleum } \\
\text { Reserve(SPR) }\end{array}$ & $\begin{array}{l}\text { Supply chain } \\
\text { agility, } \\
\text { Strategical } \\
\text { Petroleum } \\
\text { Reserve(SPR) }\end{array}$ \\
\hline 1980s & Oil supply glut & $\begin{array}{l}\text { High oil price } \\
\text { and } \\
\text { production } \\
\text { surplus }\end{array}$ & $\begin{array}{l}\text { Lesser price for } \\
\text { consumers }\end{array}$ & $\begin{array}{l}\text { manipulate } \\
\text { production rate in } \\
\text { OPEC countries, } \\
\text { store produced } \\
\text { crude oil in crude } \\
\text { stockpiles to avoid } \\
\text { extra supply in the } \\
\text { supply glut situation }\end{array}$ & $\begin{array}{l}\text { Production } \\
\text { Manipulation, } \\
\text { Crude Stockpiles }\end{array}$ \\
\hline 1990s & $\begin{array}{l}\text { Persian Gulf } \\
\text { War, Asian } \\
\text { Financial Crisis }\end{array}$ & $\begin{array}{l}\text { Low price for } \\
\text { producers, } \\
\text { unaffordable } \\
\text { new } \\
\text { investment in } \\
\text { exploration } \\
\text { and high-cost } \\
\text { production } \\
\text { fields }\end{array}$ & $\begin{array}{l}\text { Stable market for } \\
\text { consumers }\end{array}$ & $\begin{array}{l}\text { Huge merge in giant } \\
\text { IOCs }\end{array}$ & Consolidation \\
\hline $2000 s$ & $\begin{array}{l}\text { Middle East } \\
\text { conflicts, } \\
\text { Global } \\
\text { Recession }\end{array}$ & $\begin{array}{l}\text { Higher price } \\
\text { for consumers, } \\
\text { unreliable } \\
\text { supply, } \\
\text { financial crisis }\end{array}$ & $\begin{array}{l}\text { Higher price for } \\
\text { producer } \\
\text { countries }\end{array}$ & $\begin{array}{l}\text { Focus on value- } \\
\text { based management } \\
\text { derived from the } \\
\text { capital asset pricing } \\
\text { model, more } \\
\text { outsourcing, fewer } \\
\text { oil reserves } \\
\text { ownership for IOCs }\end{array}$ & $\begin{array}{l}\text { Value-Based } \\
\text { Management }\end{array}$ \\
\hline $\begin{array}{l}2010 \\
- \text { now }\end{array}$ & $\begin{array}{l}\text { Global } \\
\text { Financial crisis, } \\
\text { Environmental } \\
\text { Combat }\end{array}$ & $\begin{array}{l}\text { Environmental } \\
\text { concerns, } \\
\text { financial crisis }\end{array}$ & $\begin{array}{l}\text { Lower products } \\
\text { for consumers }\end{array}$ & $\begin{array}{l}\text { Oil production } \\
\text { manipulation, } \\
\text { expenditure } \\
\text { shrinking, new } \\
\text { technology is used } \\
\text { to produce Shale oil }\end{array}$ & $\begin{array}{l}\text { Consolidation, } \\
\text { Efficiency }\end{array}$ \\
\hline
\end{tabular}

PICBE | 515 
Table3 shows us pains, gains, and jobs to be done in each historical period by mentioning the most important historical event in each period. Events could effect on the oil industry as a fundamental factor in the desired time. After evaluating pain, gains, and jobs in PICBE | $\mathbf{5 1 6}$ each period, the most probable value propositions, based on the jobs which had done in each period, are derivate to address us desired value proposition in each period.

Our research is concentrating on the current oil industry situation which is the oil supply glut and market slow down. This situation is almost the same as the situation in the 1980s. Therefore, in our questionnaire which is designated for the semi-structured interview, 1980s' information and historical experience regarding the jobs which had done in that time, is used to shape the questions of the interview.

\section{Analysis and results}

The $1^{\text {st }}$ interview results, state that hypothesis 1 is not meet. Consolidation is not the most overwhelming value proposition. The result of the $1^{\text {st }}$ semi-structured interview is that agility and efficiency are most vital value proposition of NOC's business model. efficiency, agility and new technologies could control and decline the Production Cost of each barrel and eventually, better competition in any types of market, especially in the supply glut market situation.

Hypothesis 2, is completely supported. Iran is in a political geolocation and political pressures in recent years affected oil industry in Iran. Therefore, NIOC, try to use domestic companies. Their contracts go to one Main Contractor(MC) with an approved financial ability, then MC with NOC both choose subcontractors and service companies, which have already accredited, to handle required services from exploration to production and even required maintenances. NOC observe all contract's processes to avoid any deviation from the main contract's program.

Hypothesis 3, is supported by the $1^{\text {st }}$ semi-structured interview with IOOC. IOOC utilize domestic resources and try to localize knowledge to increase efficiency and reliability as it faces with many political risks in the Persian Gulf area.

Table 4. Achievements from the 1st interview

\begin{tabular}{|c|c|c|c|c|c|}
\hline Pains & Gains & Jobs to be done & $\begin{array}{l}\text { Value } \\
\text { Proposition }\end{array}$ & $\begin{array}{l}\text { Rejected } \\
\text { Hypothesis }\end{array}$ & $\begin{array}{l}\text { Supported } \\
\text { Hypothesis }\end{array}$ \\
\hline $\begin{array}{l}\text { - Sanctions } \\
\text { - High cost of } \\
\text { production }\end{array}$ & $\begin{array}{l}\text { - Delivery } \\
\text { without } \\
\text { latency } \\
\text { - Better } \\
\text { quality } \\
\text { products }\end{array}$ & $\begin{array}{l}\text { Decrease the } \\
\text { cost of } \\
\text { production } \\
\text { Utilize } \\
\text { Domestic } \\
\text { Resources }\end{array}$ & $\begin{array}{l}\text { - Agility } \\
\text { - Efficiency } \\
\text { - New } \\
\text { Technologies }\end{array}$ & - Hypothesis 1 & $\begin{array}{l}\text { - Hypothesis } 2 \\
\text { - Hypothesis } 3\end{array}$ \\
\hline
\end{tabular}

Source: Author's own contribution.

The $2^{\text {nd }}$ interview results, state that hypothesis 1 is supported. Consolidation is a key factor in these kinds of the market but with some difference with the same market situation in the history of the oil industry. The types of current consolidation are a union among OPEC countries and NON-OPEC countries, as OPEC countries are not the leader in the oil industry anymore. They cannot overcome the market without NON-OPEC producer countries' support. 
Hypothesis 2, is supported again as NIOC's business model like other NOCs is that utilize integrated E\&P companies to support all aspects of the contract like financial aspect, technical aspect, and other aspects which are related to required services which have to be done.

Hypothesis 3, is supported as Iran is in the sanction circumstance and there is no guaranty that any IOC could have a stable contract. Therefore, NIOC decided to utilize domestic contractors due to lack of stability and reliability in their probable contracts with IOCs.

Table 5. Achievements from the 2nd interview

\begin{tabular}{|c|c|c|c|c|c|}
\hline Pains & Gains & Jobs to be done & $\begin{array}{l}\text { Value } \\
\text { Proposition }\end{array}$ & $\begin{array}{l}\text { Rejected } \\
\text { Hypothesis }\end{array}$ & $\begin{array}{l}\text { Supported } \\
\text { Hypothesis }\end{array}$ \\
\hline $\begin{array}{l}\text { - Latency in } \\
\text { delivery } \\
\text { - Not precise } \\
\text { quantity in } \\
\text { Delivery } \\
\text { - Difficulty in deals } \\
\text { with } \\
\text { international } \\
\text { customers } \\
\text { because of } \\
\text { political } \\
\text { problems }\end{array}$ & $\begin{array}{l}\text { - Precise } \\
\text { Delivery } \\
\text { without } \\
\text { latency } \\
\text { - Deals } \\
\text { with loyal } \\
\text { customer } \\
\text { s to sell } \\
\text { cheaper }\end{array}$ & $\begin{array}{l}\text { - Build storage to } \\
\text { facilitate } \\
\text { delivery } \\
\text { - Installed precise } \\
\text { metering } \\
\text { sensors to omit } \\
\text { difference in } \\
\text { delivered } \\
\text { volume } \\
\text { - Build Stockpiles } \\
\text { - Increase the } \\
\text { recovery factor }\end{array}$ & $\begin{array}{l}\text { - Stockpiles } \\
\text { - Efficiency } \\
\text { - New } \\
\text { Technologies }\end{array}$ & $\begin{array}{l}\text { None of } \\
\text { them }\end{array}$ & $\begin{array}{l}\text { - Hypothesis } 1 \\
\text { - Hypothesis } 2 \\
\text { - Hypothesis } 3\end{array}$ \\
\hline
\end{tabular}

Source: Author's own contribution.

The $3^{\text {rd }}$ interview results, state that hypothesis 1 is not supported. OPEC countries have recently never obligated from their commitments, although they commit that avoid produce and sell their products more than specified volume, they always produce more and sell cheaper than the market unofficially to their customers. The most important players in the oil market are consumers. They always push the price to go up or down to facilitate their policies regarding investment on new technologies.

Hypothesis 2, is supported because of NIOC's business model. NIOC should award a contract to an integrated contractor as the main contractor(MC), then by NIOC's observation, utilizes accredited service companies in which required services.

Hypothesis 3, is not supported. NIOC had a great experience with IOCs whenever utilize them and award contracts to them. As NOCs should utilize new technologies and financial support, the best solution is using IOCs in compare with domestic resources to use IOCs advantages in technology and finance. Domestic resources could be utilized to observe contracts. 
Table 6. Achievements from the 3rd interview

\begin{tabular}{|c|c|c|c|c|c|}
\hline Pains & Gains & Jobs to be done & $\begin{array}{l}\text { Value } \\
\text { Proposition }\end{array}$ & $\begin{array}{l}\text { Rejected } \\
\text { Hypothesis }\end{array}$ & $\begin{array}{l}\text { Supported } \\
\text { Hypothesis }\end{array}$ \\
\hline $\begin{array}{l}\text { Avoid } \\
\text { supporting } \\
\text { environmental } \\
\text { issues } \\
\text { Knowledge } \\
\text { problem in } \\
\text { domestic } \\
\text { resources }\end{array}$ & $\begin{array}{l}\text { - Cheaper oil } \\
\text { for } \\
\text { consumers }\end{array}$ & $\begin{array}{l}\text { Increase } \\
\text { efficiency by } \\
\text { utilizing } \\
\text { knowledgeable } \\
\text { staff }\end{array}$ & $\begin{array}{l}\text { - Financial } \\
\text { power } \\
\text { - Consolidation } \\
\text { in Consumer } \\
\text { side, not NOCs } \\
\text { - Value-based } \\
\text { management }\end{array}$ & $\begin{array}{l}\text { - Hypothesis } \\
1 \\
\text { - Hypothesis } \\
3\end{array}$ & - Hypothesis \\
\hline
\end{tabular}

PICBE $\mid 518$

Source: Author's own contribution.

The $4^{\text {th }}$ interview results, state that hypothesis 1 is not supported. consolidation which could be achieved by the union between OPEC countries could not be successful as they have never obliged based on their commitments. Any changes that we have seen in the market recently, could be considered as Saudi Arabia recent political reform.

Hypothesis 2, is supported. Any splitting in any system and make contracts with different contractors are always faced with loss. Integration between those split systems has normally costs more. We also will receive lesser quality in the whole system in comparison with an integrated contract. The main contractor could have better observation and control on different parts of the contract and predict what will be required in any future phase.

Hypothesis 3, is supported. Although we prefer using international companies, we cannot utilize them because of the sanction and political problems. Therefore, we use our domestic contractors though they might have a lesser technical ability due to the sanction.

Table 7. Achievements from the 4th interview

\begin{tabular}{|c|c|c|c|c|c|}
\hline Pains & Gains & Jobs to be done & $\begin{array}{l}\text { Value } \\
\text { Proposition } \\
\end{array}$ & $\begin{array}{l}\text { Rejected } \\
\text { Hypothesis }\end{array}$ & $\begin{array}{l}\text { Supported } \\
\text { Hypothesis }\end{array}$ \\
\hline $\begin{array}{l}\text { - Fluctuation } \\
\text { in delivery } \\
\text { - Knowledge } \\
\text { problem in } \\
\text { domestic } \\
\text { resources }\end{array}$ & $\begin{array}{l}\text { - Precise } \\
\text { metering } \\
\text { system } \\
\text { - } \text { CRM }\end{array}$ & $\begin{array}{l}\text { - Utilizing } \\
\text { Electrical } \\
\text { Submersible } \\
\text { Pumps(ESP) to } \\
\text { have a better } \\
\text { efficiency } \\
\text { - Implement } \\
\text { CMMS and } \\
\text { schedule a } \\
\text { better PM } \\
\text { program } \\
\end{array}$ & $\begin{array}{l}\text { - Efficiency } \\
\text { - Stockpiles } \\
\text { - Value-based } \\
\text { management }\end{array}$ & - Hypothesis 1 & $\begin{array}{l}\text { - Hypothesis } 2 \\
\text { - Hypothesis } 3\end{array}$ \\
\hline
\end{tabular}

Source: Author's own contribution.

The $5^{\text {th }}$ interview results, state that hypothesis 1 is mostly supported. consolidation could be the solution as a value proposition in short-term and mid-term, but not in longterm. Many situations could be changed in long-term and there is no much chance for NOCs to compete with their rivals if they only rely on consolidation and their fossil energy resources.

Hypothesis 2, is completely supported. If we want to have a better result, we should integrate all state companies of a NOC from upstream to downstream as a portfolio to 
support each sector by other complementary sectors and avoid some extra costs derived from ownership changes in any existing sectors. We can have a lower monetary overhead and compensate any probable loss while all sectors could cover each other like the stock market. Therefore, one of the most important solutions or value proposition is integrated value chain

Hypothesis 3, is not supported. There is no chance for any NOC to survive without any knowledge or financial support. By a desired regulatory model, we can use domestic resources and improve their knowledge by the required partnership with IOCs.

Table 8. Achievements from the 5th interview

\begin{tabular}{|c|c|c|c|c|c|}
\hline Pains & Gains & Jobs to be done & $\begin{array}{l}\text { Value } \\
\text { Proposition }\end{array}$ & $\begin{array}{l}\text { Rejected } \\
\text { Hypothesis }\end{array}$ & $\begin{array}{l}\text { Supported } \\
\text { Hypothesis }\end{array}$ \\
\hline $\begin{array}{l}\text { Reliable } \\
\text { energy } \\
\text { resources }\end{array}$ & 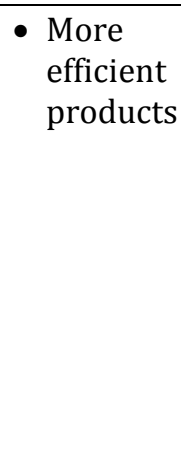 & $\begin{array}{l}\text { - Providing } \\
\text { integrated value } \\
\text { chain } \\
\text { - Better Partnership } \\
\text { model with other } \\
\text { NOCs and IOCs } \\
\text { - Regulatory to } \\
\text { avoid government } \\
\text { dominance } \\
\text { - Improving fiscal } \\
\text { regime }\end{array}$ & $\begin{array}{l}\text { - } \text { Becoming } \\
\text { National Energy } \\
\text { Company(NEG) } \\
\text { - Asset } \\
\text { Management } \\
\text { - Integrated value } \\
\text { chain } \\
\text { - Achieving } \\
\text { renewable } \\
\text { energy } \\
\text { - partnership }\end{array}$ & - Hypothesis & $\begin{array}{l}\text { - Hypothesis } 1 \\
\text { - Hypothesis } 2\end{array}$ \\
\hline
\end{tabular}

Source: Authors' own contribution.

\section{Conclusions}

The Value proposition is one of the crucial parts of each business model which any products and services of each firm rely on it. To achieve a value proposition, different methods exist. We use Osterwalder method in this article to obtain value proposition of NOCs which are the most important stakeholders in the oil industry.

Research on the value proposition in the oil industry history by doing a literature review on historical references has done and it was classified into twelve periods from the 1850 s to 2010s. Value proposition from each decade has derivate with any pain, gain, and job which had done in each period by mentioning the most important historical information and events in each decade.

The main objective of this research is to develop the value proposition for the business model for National Iranian Oil Companies(NIOC). And the methodology of this research is the semi-structured interview which has done by five current or previous senior managers of NIOC. They answered designated questions and gave their ideas based on their companies' experiences while they also told their comments about the oil industry and its future. Some deficiencies were also discovered which they mentioned their companies' solutions to face with them.

To summarize interview's results regarding the article's hypotheses and desires value propositions for NOCs in the market supply glut situation following achievements are derivate. The most supported hypothesis is hypothesis- 2 which all five interviewees believed that it is true, while the most rejected hypothesis is hypothesis-1 with three rejected comments. Therefore, we strongly can support this hypothesis that NOCs have the 
better efficiency if they make contract with an integrated Exploration and Production(E\&P) companies instead of splitting the contract among different service companies, and strongly reject this idea that Consolidation is the most overwhelming value proposition for NOCs to revive the market. Hypothesis- 3 is also in a moderate state with three supports and two rejects. Regarding value propositions, we can recap following value propositions. Becoming National Energy Company(NEG), Asset Management, Integrated value chain, Achieving renewable energy, partnership, Efficiency, Stockpiles, Value-based management, Financial power, Consolidation in Consumer side, not NOCs, Agility, New Technologies. From aforementioned value propositions, the most mentioned value propositions by considering supported and rejected hypotheses could be Efficiency and Value-Based Management by considering renewable energy achievement.

\section{References}

American Chemical Society (2017). Development of the Pennsylvania Oil Industry National Historic Chemical Landmark - American Chemical Society. [ONLINE] Available at: https://www.acs.org/content/acs/en/education/whatischemistry/landmarks/p ennsylvaniaoilindustry.html. [Accessed 11 September 2017].

Bennett H. Wall et al. (1988). Growth in a Changing Environment: A History of Standard Oil Company (New Jersey), 1950-1972, and Exxon Corporation, 1972-1975.

Cleverism. (2017). Business model canvas: Creating a Value Proposition. [ONLINE] Available at: https://www.cleverism.com/business-model-canvas-creating-valueproposition/. [Accessed 05 September 2017].

Daniel Yergin (1990). The Prize: The Epic Quest for Oil, Money, and Power.

David A. Aaker, (1996), Building Strong Brands, The Free Press New York. en.mop.ir. (2017). [ONLINE] Available at:

http://en.mop.ir/Portal/home/?generaltext/4012/4187/165293/Mission. [Accessed 30 November 2017].

Engelman, Ryan. (2015). "The Second Industrial Revolution, 1870-1914." US History Scene. 10 Apr. 2015.

HISTORY.com. (2017). Oil Industry - Facts \& Summary - HISTORY.com. [ONLINE] Available at: http://www.history.com/topics/oil-industry. [Accessed 20 September 2017].

Liam Denning. (2017). The Oil Glut Rewrites History - Bloomberg Gadfly. [ONLINE] Available at: https://www.bloomberg.com/gadfly/articles/2017-08-17/opeccutbacks-are-diluted-by-oil-s-long-bloat. [Accessed 09 October 2017].

McNally, R. (2017). Crude Volatility. Columbia University Press. ISBN: 9780231543682

Michael Skok. (2013). 4 Steps to Building A Compelling Value Proposition, [ONLINE] Available at: https://www.forbes.com/sites/michaelskok/2013/06/14/4-steps-tobuilding-a-compelling-value-proposition/\#46faa7a74695. [Accessed 30 October 2017].

OilPrice.com. (2017). The 5 Biggest Strategic Petroleum Reserves In The World | OilPrice.com. [ONLINE] Available at: http://oilprice.com/Energy/EnergyGeneral/The-5-Biggest-Strategic-Petroleum-Reserves-In-The-World.html. [Accessed 09 October 2017].

OPEC: Brief History. (2017). OPEC: Brief History. [ONLINE] Available at: http://www.opec.org/opec_web/en/about_us/24.htm. [Accessed 11 October 2017]. 
Pamela Hudadoff. (2009). The Customer Value Proposition Differentiation through the Eyes of Your Customer, Applied Product Marketing LLC.

Panmore Institute. (2017). Tesla Motors, Inc.'s Vision Statement \& Mission Statement (An Analysis) - Panmore Institute. [ONLINE] Available at: http://panmore.com/teslamotors-inc-vision-statement-mission-statement-analysis. [Accessed 30 November 2017].

Paul A. Haslam, Pablo Heidrich. (2016). The Political Economy of Natural Resources and Development: From Neoliberalism to Resource Nationalism. Routledge. ISBN: 9781317418917

Paul H. Giddens, (1938). The Birth of the Oil Industry.

Pollution causes, effects and solutions. (2017). Pollution causes, effects and solutions. [ONLINE] Available at: https://www.slideshare.net/zizou27300/pollution-causeseffects-and-solutions. [Accessed 14 September 2017].

Ralph W. and Muriel E. Hidy (1955). Pioneering in Big Business, 1882-1911.

Stevens, P. (2017). International Oil Companies. Chatham House. ISBN: 9781784131234

Tantau A., Staiger R. (2017). Business Models for Renewable Energy Initiatives: Emerging Research and Opportunities, IGI Global

U.S. Crude Oil First Purchase Price (Dollars per Barrel). (2017). U.S. Crude Oil First Purchase Price (Dollars per Barrel). [ONLINE] Available at: https://www.eia.gov/dnav/pet/hist/LeafHandler.ashx?n=pet\&s=f000000_3\&f=a. [Accessed 07 October 2017].

US EPA. (2017). Climate Change Indicators: Greenhouse Gases | Climate Change Indicators in the United States | US EPA. [ONLINE] Available at: https://www.epa.gov/climateindicators/greenhouse-gases. [Accessed 21 September 2017]. 